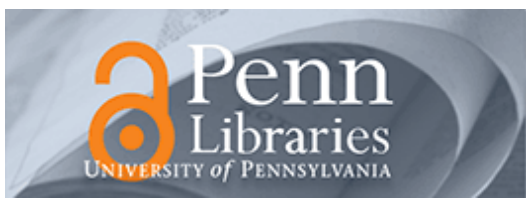

University of Pennsylvania ScholarlyCommons

Wharton Pension Research Council Working

Papers

Wharton Pension Research Council

$1-1-2005$

\title{
Strategic Asset Allocation in Japan: An Empirical Evaluation
}

Tokuo Iwaisako

Hitotsubashi University, iwaisako@ier.hit-u.ac.jp

Olivia S. Mitchell

The Wharton School, University of Pennsylvania, mitchelo@wharton.upenn.edu

John Piggott

University of New South Wales, j.piggott@unsw.edu.au

Follow this and additional works at: https://repository.upenn.edu/prc_papers

Part of the Economics Commons

Iwaisako, Tokuo; Mitchell, Olivia S.; and Piggott, John, "Strategic Asset Allocation in Japan: An Empirical Evaluation" (2005).

Wharton Pension Research Council Working Papers. 375.

https://repository.upenn.edu/prc_papers/375

This paper is posted at ScholarlyCommons. https://repository.upenn.edu/prc_papers/375

For more information, please contact repository@pobox.upenn.edu. 


\title{
Strategic Asset Allocation in Japan: An Empirical Evaluation
}

\begin{abstract}
This research seeks to provide a comprehensive picture of lifetime asset allocation in Japan. We evaluate patterns in the level and composition of assets by household type, taking account of home ownership and household claims on social security as well as financial assets and pensions. The analysis relies on a micro-data taken from the RADAR survey fielded by Nikkei, for the year 2000. The RADAR data are the only publicly available dataset to record financial asset holdings in any detail, with which we calculate housing equity as well as other forms of wealth. We supplement this with external information on pension and social security entitlements. The resulting picture attests to the importance of housing and social security in the portfolios of households approaching retirement. As well, we compare asset allocation patterns between those who are worse vs. better off, better vs. worse educated, married couples vs others, and dualearner vs. single earner couples. Our econometric analysis of asset allocation choice reinforces priors regarding Japanese lifecycle asset allocation patterns: households do invest conservatively, other than their family home; they are riskaverse in their allocation of financial assets; and they appear to over-invest in housing and life insurance, two assets which enjoy preferential bequest tax treatment. We argue that institutional, historical, and policy influences explain much of observed Japanese preferences for safe financial assets, and we offer suggestions for mechanisms that could increase household diversification.
\end{abstract}

\section{Disciplines}

Economics 


\title{
Strategic Asset Allocation in Japan: An Empirical Evaluation
}

\author{
Tokuo Iwaisako, Olivia S. Mitchell, and John Piggott
}

PRC WP 2005-1

Pension Research Council Working Paper

\author{
Pension Research Council \\ The Wharton School, University of Pennsylvania \\ 3620 Locust Walk, 3000 SH-DH \\ Philadelphia, PA 19104-6302 \\ Tel: 215.898.7620 • Fax: 215.898.0310 \\ Email: pre@wharton.upenn.edu \\ http://prc.wharton.upenn.edu/prc/prc.html
}

Pension Research Council Working Papers are intended to make research findings available to other researchers in preliminary form, to encourage discussion and suggestions for revision before final publication. Opinions are solely those of the authors.

Funding for this research was provided by the Economic and Social Research Institute, the Japan Society for the Promotion of Science, the Project on Intergenerational Equity (Hitotsubashi University), the Pension Research Council and Boettner Center at the Wharton School of the University of Pennsylvania, and the Australian Research Council. Without implicating them, we acknowledge helpful assistance and suggestions from Rochelle Belkar, Noriko Inakura, Henry Jin, Masaharu Usuki, and Takeshi Yamaguchi, as well as seminar participants at the ESRI. This paper was presented at the Tokyo, Japan, February 2004 International Collaboration Forum organized by the ESRI, Cabinet Office, Government of Japan.

C2004 Pension Research Council of the Wharton School of the University of Pennsylvania. All Rights Reserved. 


\title{
Strategic Asset Allocation in Japan: An Empirical Evaluation
}

Tokuo Iwaisako, Olivia S. Mitchell, and John Piggott

\begin{abstract}
$\underline{\text { Abstract }}$
This research seeks to provide a comprehensive picture of lifetime asset allocation in Japan. We evaluate patterns in the level and composition of assets by household type, taking account of home ownership and household claims on social security as well as financial assets and pensions. The analysis relies on a micro-data taken from the RADAR survey fielded by Nikkei, for the year 2000. The RADAR data are the only publicly available dataset to record financial asset holdings in any detail, with which we calculate housing equity as well as other forms of wealth. We supplement this with external information on pension and social security entitlements. The resulting picture attests to the importance of housing and social security in the portfolios of households approaching retirement. As well, we compare asset allocation patterns between those who are worse vs. better off, better vs. worse educated, married couples vs others, and dualearner vs. single earner couples. Our econometric analysis of asset allocation choice reinforces priors regarding Japanese lifecycle asset allocation patterns: households do invest conservatively, other than their family home; they are risk-averse in their allocation of financial assets; and they appear to over-invest in housing and life insurance, two assets which enjoy preferential bequest tax treatment. We argue that institutional, historical, and policy influences explain much of observed Japanese preferences for safe financial assets, and we offer suggestions for mechanisms that could increase household diversification.
\end{abstract}

\section{Tokuo Iwaisako}

Institute of Economic Research, Hitotsubashi University

2-1 Naka, Kunitachi-city, Tokyo 186-8603, JAPAN

E-mail: iwaisako@ier.hit-u.ac.jp

Olivia S. Mitchell

The Wharton School, University of Pennsylvania

Philadelphia, PA 19104 USA

e-mail: mitchello@wharton.upenn.edu

John Piggott (corresponding author)

School of Economics, University of New South Wales

Sydney 2052, Australia

e-mail: J.Piggott@unsw.edu.au 


\section{Strategic Asset Allocation in Japan: An Empirical Evaluation}

Tokuo Iwaisako, Olivia Mitchell, and John Piggott

Understanding how asset levels and wealth composition vary over the lifecycle is of increasing interest to economists and policymakers concerned with retirement security. It is now clear that rapid population aging is coinciding with grave challenges to traditional institutions on which people relied for retirement income. For instance, defined benefit occupational pension plans, once perceived as secure, now face massive funding deficits in virtually every nation. Government-run Social Security/public pensions are also seriously under-financed; casting doubt on what people in many developed countries have anticipated would be their main pillar of retirement security. Equity markets, which for decades in the Western world were believed to be the engine of wealth creation, are now seen with suspicion pursuant to the poor stock market performance of the last few years.

As the most rapidly aging nation in the world, Japan is keenly aware of many of these developments. In recent years, Japan's national social security system has been forced to undergo several reforms substituting price for wage indexation and various other changes in both the benefit and tax formulas (Takayama, 2001, 2003). Deep funding problems in the Japanese occupational defined benefit pension system have driven many firms to terminate their plans

recently, while others have moved toward defined contribution plans. ${ }^{1}$ Until the Japanese "bubble" burst, equity markets had been viewed as a good long-term bet, but after a decade of nonperformance, few now see equities as a safe investment (Nakagawa and Shimizu, 2000). These changes in perception suggest that an investigation of household asset allocation over the 
lifecycle in Japan is of substantial interest not only for Japanese scholars, but for the rest of the developed world as well.

How Japanese households allocate their wealth, and how this might change in the future, will also be very important for understanding the impact of ongoing structural change in the Japanese financial system. Iwaisako (2003) points out that one aim of the recent structural reforms has been to move away from the old bank-oriented financial system and toward a more market-oriented system of pricing risk. While the focus of most financial analysis on this subject has been on corporate finance and governance, ${ }^{2}$ we contend that it just is as important to investigate how households allocate their funds as they do, and to evaluate what factors influence these choices. As the financing of Japan's business sector changes, so too must household finances change in years to come.

In what follows, we first review available international evidence on aggregate household asset patterns for several European nations, the US, and Japan. Next, we turn to a more finelydetailed analysis of lifecycle asset holding patterns in Japan using a microeconomic crosssectional dataset from Nikkei. These survey data, along with associated other information, permits us to determine how asset levels and asset mix changes over the lifecycle as well as along other dimensions. Finally, we investigate whether factors specific to Japan seem to inhibit efficient allocation of assets during both the accumulation and decumulation phases. The discussion concludes with an assessment of whether asset allocation could be improved through the development of a more comprehensive array of contractual saving and investment products.

\section{Comparative Household Asset Allocation Patterns: An Aggregate Perspective}

Two stylized facts are brought up whenever household asset allocation behavior in Japan 
is discussed: first, that the Japanese are enthusiastic savers; and second that their asset allocation tends to be extremely conservative. Table 1 provides partial support for these generalizations, drawn from Babeau and Sbano (2003). First, we note that financial wealth is relatively larger in Japan than in Europe or the US, as a percentage of disposable income. In absolute terms, however, the average US household is $50 \%$ wealthier than its Japanese counterpart. Second, residential property wealth is highest in Japan of the three regions examined, despite the last decade of falling property values. Third, financial liabilities in Japan are the highest of the regions considered, as a percentage of disposable income. Consumer debt is less important in Japan then the US or Europe; rather, debt reported consists mainly of housing debt and professional debt.

\section{Table 1 here}

Additional insight is gained from Table 2, which provides a breakdown of financial assets by type. Broadly speaking, Japan differs from other regions in having a much lower proportion of equity holdings, and a much larger proportion of bank-type deposits. Thus Japanese households hold more than half their financial wealth in deposit-type accounts, which contrasts with a bit over one-quarter of the (much lower) total in Europe, and just over 10\% in the US. In contrast, shares, other equities, and mutual funds make up just over $10 \%$ of a typical Japanese household's financial wealth, but they comprise more than one-third in Europe, and more than one-half in the US. Given these differences, it is remarkable that life insurance and pensions account for one-quarter to one-third of financial wealth in all three regions.

\section{Table 2 here}

The remaining non-human wealth of the household sector comprises claims on pension 
plans and social security. No internationally comparable estimates are available on these forms of wealth for 2000 , but in 1995 , such claims were estimated at $73 \%$ of household financial wealth in Japan, 133\% in Europe, and 45\% in the US (Babeau and Sbano, 2003).

\section{Additional Aggregate Evidence for Japan}

The onset of demographic ageing has led to renewed academic interest in issues of strategic financial asset allocation over the life-cycle. As McCarthy (2003) has noted, there is a burgeoning theoretical and empirical literature which tries to explain household asset allocation decisions and how these change over the lifetime. A striking feature of much of this literature is that it pays scant attention to the most important non-human assets available to individuals or households approaching retirement - housing and social security. We believe that little of relevance can be said about asset allocation unless these are included in the analysis. The different kinds of risks and returns that are associated with these assets must be recognized in any integrated assessment of overall asset allocation choice. But frequently, data on housing wealth and the value of rights to social security are unavailable, so that empirical analysis fails to consider them. Further, the classical analysis of asset allocation across "safe" and "risky" assets (Merton 1969, 1971) encourages empirical analysts to parse assets into these traditional categories.

Several previous studies have analyzed household portfolio choice in Japan. Nakagawa and Shimizu (1999) use Tobit and Probit models to analyze why Japanese households are reluctant to invest in risky assets. Using micro-unit data from the Family Savings Survey for 1991 and 1999, they find that "households have become more reluctant to invest in risky assets mainly as a result of the deterioration of the profit environment caused by the slumping stock 
market and because of the precautionary savings motive . . triggered by the deteriorating income environment" (p.15). They also point out that after World War II, various tax-related and institutional factors made safe assets relatively attractive. They go on to predict that financial liberalization will encourage investment in risky assets.

Because their analysis was restricted to two years, both occurring after the bubble, Nakagawa and Shimizu do not have a stable benchmark against which to measure changes in underlying Japanese asset choice. In fact, stock holdings by Japanese households increased rapidly in the late 1980 s, so the observed fall in the share of equity in financial asset portfolios from the early 90 s could be at least partially seen as an adjustment back towards the status quo. Further, they were unable to examine aggregate household wealth and asset allocation, because their data source covered only financial assets. Insurance and pensions were included, but not housing or social security. Their analysis therefore omitted the two most important sources of non-human wealth for most households.

More recently, Iwaisako (2003) studied the relationship between portfolio choice and age for Japanese households. Using micro-data from the RADAR survey, he devoted particular attention to the interaction between decisions to hold stocks versus real estate. He pointed out that housing is a risky investment, and that because of high house prices, Japanese households are exposed to considerably more leveraged risk than their US counterparts. This effect is partially mitigated by the higher down payment typically required in Japan (20\%), versus the usual minimum down payment of $10 \%$ (or less) in the US.

In spite of high prices, buying homes in Japan is often preferred to renting, for tax reasons. In particular, there is preferential treatment of imputed income under the income tax. 
Further, there is also preferential treatment of housing under bequest tax arrangements (Nakagawa and Shimizu, 2000).

\section{Detailed Evidence on Asset Allocation Patterns in Japan by Age and Household Type}

Drawing on a range of information, we seek to construct a picture of the pattern and level of assets for different household types. The major components of household wealth which must be quantified in the Japanese context include: the net value of financial assets, the value of life insurance, the value of net housing wealth, the present value of social security entitlements, and the present value of pension entitlements. In what follows, we begin by describing how we construct the requisite information household portfolios, and then we turn to the results.

Piecing Together the Asset Allocation Picture: An Overview of Sources and Methods

In order to provide a better picture of lifetime asset allocation in Japan by household type, we use a range of data sources. We rely for the analysis on the RADAR dataset assembled by Nikkei, a comprehensive unit record data set that reports financial asset holdings in great detail. In this paper, we use data for the year 2000 (in the future we hope to extend our work to include additional years.) The RADAR information on housing allows us to calculate housing net equity, and we supplement this with external information on pension holdings and social security entitlements. One advantage of using year 2000 information is that it is relatively recent data, an important consideration given the probable impact of a decade of recession on asset allocation.

The RADAR survey for the year 2000 had a usable sample of about 2,500 individuals between the ages of 25 and 74 (for additional detail on the survey, see the Appendix). This survey provides values of financial assets reported directly; equity holdings can then be subtracted from "all financial assets" to arrive at separate valuations of "equities" and "other 
financial assets". As such, the RADAR dataset has several strengths and a few weaknesses. First, it covers mainly the Tokyo metropolitan area and surrounding prefectures (Iwaisako, 2003). Therefore it is mainly representative of the urban segment of the Japanese population. Second, while the survey asks questions of individuals, many assets are owned by the households in which they reside. So the financially knowledgeable member of a couple (the "one who decides their budget") is supposed to answer the financial questions, while other questions are answered by the age-eligible respondent. This approach is consistent with the one taken in many other surveys of financial wellbeing (e.g. the Health and Retirement Study in the US), and it is believed to generate good-quality financial data for households. On the other hand, household assets are reported in toto and cannot be identified according to which person owns which item. This makes it difficult to separate out ownership of assets for multigenerational households, including elderly persons who live with their adult children.

The RADAR survey does ask about housing wealth in some detail. Where complete information was given, this enabled calculation of the net value of owner-occupied housing (less outstanding debt). In about one-quarter of the cases, however, incomplete data were given on housing debt so these observations were excluded. It is possible that this introduces a bias into estimates; further research will be required to assess this possibility. ${ }^{3}$

Another aspect of the RADAR survey is that it lacks direct estimates of pension and social security wealth. However we are able to impute values for these key asset components using the fact that these entitlements in Japan are individually-based. Social security has two components - a basic pension, and an earnings related component called the EPI. Contributions are required for entitlement to either of these benefit types. We have assumed that contributions 
are made for both spouses in our married households, and that therefore a single person is entitled to a single basic pension, and a married couple to two basic pensions. The RADAR data do not report labor earnings of individuals, so social security benefits were allocated based on an imputed salary. Determining the household head's estimated salary relied on age-earnings profiles for individuals in 2000, differentiated by educational level, published by the Japanese Department of Labor.

Corporate pension entitlements are not captured in the RADAR dataset. It is interesting that this otherwise comprehensive survey devoted only a single question to pension entitlements, and it simply asked whether the subject received a current pension and its value. No distinction was made as to the source of the pension - it could have been a lump sum payment, a corporate pension annuity, a private annuity, or even a social security benefit. We therefore made use of estimated present values of pensions reported in Usuki (2003). ${ }^{4}$ These are distinguished by age and educational level. We assume that all salary earners belonged to a corporate pension plan, using the salary flag in the RADAR data set to identify these individuals, along with their educational level.

The computations of social security and pension wealth accumulations use the Accumulated Benefit Obligation (ABO) approach to valuation rather than a Projected Benefit Obligation (PBO) approach. The ABO value has the advantage that social security and pension entitlements earned to date are thus computed in a manner consistent with the valuation of other assets. For example, the value of an owner-occupied dwelling for a couple age 40 in 2000 is its value in that year, not the present value of its projected worth in 2020. Of course, applying the ABO principle implies that the reported value of a social security (or pension) entitlement is zero 
until vesting occurs. In the case of social security in Japan, benefit entitlement occurs after 25 years of contribution, so the estimates presented below report zero social security wealth for households with heads are younger than age 45.

Our approach, building on RADAR, enables us to generate estimates for all important household assets except for life insurance since data limitations preclude quantification of this asset class. ${ }^{5}$ The picture we generate below illustrates the importance of housing and social security in the overall wealth portfolios of Japanese households approaching retirement. As well, we are able to indicate differences in asset allocation patterns between the better and worseeducated, married couples and others, the worse and better off, and couples with varying employment status. We then exploit the micro-unit nature of our data to carry out an econometric analysis of asset allocation choice.

\section{$\underline{\text { Descriptive Results }}$}

We next present information on the comprehensive household wealth profiles we have devised by age and also by household type. Table 3 provides summary statistics, where we see that for all wealth and income measures, means are somewhat higher than the medians due to the skewness of the distributions. Social security wealth is relatively smoothly distributed, with both the mean and the median household surveyed anticipating around $¥ 20-24$ million in present value (about \$200-230,000 US as of 1-04); net housing equity vies for second place in the asset rankings, but it is far less equally distributed, with the mean totaling $¥ 24$ million while the median is less than half that sum. Pension and non-equity assets are the next most important asset, but these account for only around US\$60-80,000 on average, but only half that for the median household. Total wealth amounted to $¥ 50-70$ million yen (US\$480-610,000) depending 
on whether one uses the median or mean, with the latter figure being the higher one. The final column reports household monthly income, which in this sample averaged about $¥ 6-7$ hundred thousand (US\$6-7,000) per month.

\section{Table 3 here}

Figure 1 gives the overall asset allocation results, where households are distinguished only by age of household head. ${ }^{6}$ A first message to be drawn from Figure 1 is the overwhelming importance of owner-occupied housing and social security in Japanese life cycle asset allocation. Until the household head reaches his 40 s, there is relatively little accumulation of assets in the Japanese context. Only after this age do many households purchase their own homes. This is a later point in the lifecycle than in typical Western countries, partly because of the high price of housing in Japan, and partly because lenders generally require a $20 \%$ down payment on homes in Japan, versus $10 \%$ in comparator countries.

\section{Figure 1 here}

In Japan, social security, and, frequently, corporate pensions, are vested from age 45 . For this reason, Figure 1 also reveals a sudden jump between the calculated wealth of 40-44 yearolds and that of persons age 45-49. Home equity increases, corporate pensions rise in present value terms, and most importantly, social security becomes vested. Social security remains on average the most important asset until we reach the over 65 group, at which point we truncate our groupings due to lack of sample size over that age.

It is frequently claimed that in Japan (and elsewhere) that asset drawdown does not occur among the elderly, possibly because of a bequest motive or extreme risk aversion. The comprehensive data in Figure 1, however, confirm that asset decumulation indeed occurs in 
Japan after the age of 65. Most of the decline observed appears to be attributable to the fall in the calculated present value of social security with age, but corporate pensions are frequently paid out as lump sums, and their value certainly collapses after the age of 60 in our dataset without compensating increases in other financial assets. It seems probable that the lump sum payout is often used to pay off the mortgage, and that this explains the sudden, and important, rise in housing equity between the 55-59 age group and those five years older.

We next turn to the employment status of the secondary worker, who is assumed to be the wife. Figures $2 \mathrm{a}-\mathrm{c}$ offer some contrasts in life cycle asset accumulation and allocation patterns, as a function of the wife's market employment status. Once social security is vested, the couple's social security wealth is also higher, though it is interesting that the difference is far less than might be expected. This is mainly because of the importance of the basic pension in overall social security arrangements in Japan, which remains relatively level over the lifecycle. Relatively little additional benefit flows to households from social security if there are two fulltime workers. This may help to explain the relatively low labor force participation rates of married women in Japan. Though much less important, a similar observation can be made about the value of the corporate pension entitlement. In fact, couples with a non-working spouse do just as well from the corporate pension as do full-time couples, possibly reflecting higher salary payments commanded by primary workers with non-working spouses.

Figures $2 a-c$ here

Early in the lifecycle, couples who both work full time tend to enter the housing market younger than households with a non-working spouse, though not dramatically so. Late in life, housing wealth is appreciably higher for couples where both spouses work full-time, and this 
accounts for most of the difference in overall wealth between these groups late in life. Through most of the observed age groups, there is not much difference between holdings of bank-type deposits by spouse employment status.

Finally, aggregate asset decumulation late in life is observed only in households where the spouse does not hold a job outside the home. Reasons for this are unclear: one possibility is that where both spouses are working, secondary labor force participants are younger, and continue to contribute positively to household wealth even when the household head is over 65 .

Figures $3 \mathrm{a}$ and $\mathrm{b}$ report lifecycle asset levels and composition for single males and females. Early in the lifecycle, a pattern of gradual accumulation is observed. From the midforties, however, clear patterns disappear and interpretation is difficult, partly because of changing household composition. Thus some single persons remain unmarried their entire lives, while others marry late, still others are married early and become single through death or divorce late in the lifecycle. ${ }^{7}$ Nevertheless, two general points may be made. First, overall wealth for singles is little more than half that enjoyed by couples. Second, asset decumulation late in life is present for both males and females, but is particularly marked for females. This suggests that widowhood may play an important role in this subpopulation.

Figure 3 here

Figure 4 disaggregates households by family income quartile. The first panel depicts asset allocation in the highest quartile of household income; the second panel covers the middle two quartiles; the lowest panel reports results for the bottom quartile. Early in the lifecycle, the high income quartile records significantly higher asset holdings than the other groups. Before the age of 30 , home equity comprises most of the wealth of this group, probably reflecting early 
inheritance. Through the 30s and early 40 s, as more households enter the top quartile, overall wealth remains high, but median values indicate pension and deposit wealth become more important.

Figure 4 here

From the mid 40s, the most important asset differentiating the high income group from others is housing. This remains true throughout the lifecycle, although pension and other financial asset wealth is also significantly higher for the top income quartile in older age groups. Housing is particularly important in the over-65 age group. This may be attributable to a cohort effect: household heads age 65 in 2000 would likely have bought into the housing market in the early 80 s, before the bubble, and even in the face of declining property values in the $90 \mathrm{~s}$, would still have benefited from the capital gain accruing to housing over the last quarter century. The middle income group presents a conventional lifecycle accumulation decumulation pattern. Early asset accumulation is predominantly corporate pension entitlements and deposits, home equity becomes significant in the mid forties, along with social security, which is vested at that point. Decumulation after retirement is mostly due to the decline in the value of expected remaining social security payments.

The most important differentiating feature of asset composition in the low income quartile is again housing. It might be expected that, controlling for age, the highest proportion of non-owners fall into this group. But median values of other assets are low too, about half the value recorded for the middle income group, and less than one third that of the rich. Deposits are lower by similar proportions, but in absolute terms are less important. In the lowest quartile, decumulation after retirement appears related not only to reducing social security value, but to a 
decline in home equity as well.

This latter effect is absent in higher income groups. Its exact nature is unclear. It is possible that some poor elderly are selling their homes and moving in with relatives, or into nursing homes. They may also be transferring title in their homes to their children. Home equity loans and reverse mortgages are not common in Japan, so increasing indebtedness appears an unlikely explanation.

The descriptive material presented thus far offers some interesting questions concerning lifecycle asset allocation in Japan. They are probed more systematically with regression analysis in the next section.

\section{Econometric Analysis of Portfolio Allocations}

In this section we use multivariate analysis to investigate several questions that arose from our earlier discussion. First, we wish to test the hypothesis that age-related patterns in wealth levels and portfolio mix are statistically significant, after holding other factors constant. Second, we seek to assess whether household composition influences wealth levels and mix: specifically, we can test whether wealth levels are higher, and risk composition changes, if the spouse is employed. Third, it is of interest to evaluate the link between family income and wealth levels as well as portfolio mix. In particular we can test whether income is nonlinearly related to total wealth and wealth components.

The decision to hold/not a particular asset is investigated with a Probit model in Table 4, which reports coefficient estimates for equity holding and housing tenure, estimated separately for single males, single females, and couples. We do not report results for corporate pension or social security, since these are imputed using explanatory variables as described above. 
Furthermore in this cross-section, too few non-participating observations exist for non-equity holdings to do the 0,1 comparison. For couples, Table 4 indicates positive and generally rising age effects in the equity equation to age 55-64 with a further positive age patterns after that; a similar pattern is seen for single women though small sample sizes hold down significance. (The reference category is younger than age 35). Equity holding for single males appear to peak at 5564 and flatten out thereafter. For housing ownership, the Table shows strongly positive age effects again for couples, with the probability of having a home rising to age 75 . Small sample sizes render many of the age coefficients for single individuals not statistically significant. But the clear age-related patterns in equity and housing tenure are confirmatory of the findings in the figures discussed earlier.

\section{Table 4 here}

The Probit models also control on education, household income, and employment status of the respondent (and spouse, if relevant). Not surprisingly, education always enters positively for equity holding in the singles and the couples' models. By contrast, education is not significant in the housing models, though because we also control on age and income, it is not particularly surprising. Household income enters positively in both housing and equity models, while income squared has a negative impact; these findings stand out most clearly in the case of couples where the sample sizes are larger. The fact that both holding equity and housing are a concave function of household income is interesting, suggesting that better-off couples are more likely to diversify. Overall the results appear reasonable, though the coefficient on household head's employment status requires some explanation. It proves to be negative and statistically significant in the equity regression for couples and the housing regression for single male and 
couples, and it suggests that if the head is not working, wealth is higher. We speculate that this employment status variable may be indicative of the head's being retired, something we will explore in future work.

Next we turn to Table 5 which evaluates patterns of wealth levels for equity and housing wealth for the pooled sample. We use Tobit regression to take into account that some fraction of the sample does not hold the asset in question, and hence is censored at 0 . It is again interesting that there are very strong age effects, as before. Specifically, the effect of age is positive and increasing with age, and the coefficients are strongly statistically significant and large in absolute magnitude. Furthermore, as people age, their real estate wealth grows much faster than their equity investments, by about an order of magnitude. Clearly people still see housing as a more attractive form of saving than the stock market.

\section{Table 5 here}

Turning to other variables, education has a positive effect on wealth levels, though the effect is stronger for equity holdings and not significant for housing. Men are more likely to report higher equity and housing wealth levels ( $\operatorname{sex}=1$ signifies male), and there appears to be no difference between married and non-married households. Income effects have an interesting pattern: for equity wealth, income enters positively but at a decreasing rate, while in the housing equations it has a positive and growing link with wealth. We also explored some interaction terms, of which "married*income" and "income*older (65-74)" are significant.

Additional Tobit analysis disaggregating asset holdings by marital status is presented in Table 6. Focusing first on equity wealth, again we see strong age-related patterns in the equity level regressions, particularly for couples where the age effect is positive and increasing with 
age. The effect of education is again positive but most influential for single females and couples (in the latter case, husband's education is positive while the wife's is not). Household income enters strongly positively for single women and married people; further it appears to be rising at a decreasing rate. Perhaps this is not surprising, since traditionally the very rich in Japan have been more likely to devote their wealth to real estate than to equities. Since there are limited numbers of observations who hold equity (=uncensored) among single males and females, regression results for these groups cannot be taken too seriously. Employment status is generally negative when significant, which is somewhat of a puzzle unless one hypothesizes that many working couples are saving for a house, hence may be unlikely to invest in equities until after the home purchase has taken place.

\section{Table 6 here}

Turning to the second panel, we see results for non-equity financial wealth, which include all financial assets except equity and housing wealth. The small number of censored observations for singles suggests the results would resemble those from OLS regression. Among married couples, there are clear age-related patterns with those younger than 35 having substantial savings, and the financial assets dropping suddenly for people 35-44 when they tend to purchase their first homes. Thereafter, financial assets are gradually built up again, with persons 65-74 finally having more than their very young counterparts. It is interesting that men's education is not significant in any of the models, but more educated women are more likely to hold these non-equity financial assets - most likely in the form of postal system saving. Household income is positive and statistically significantly related to this form of financial wealth, for all three groups, and at a declining rate for couples. 
The third panel of Table 6 focuses on the levels of household social security wealth, which it will be recalled are derived by applying the institutional rules to imputed household members' earnings. This implies that interpreting these regression results can be a bit problematic due to collinearity. For instance social security wealth is not vested until workers complete a certain numbers of years of employment; consequently respondents younger than age 44 are ineligible for accrued benefits. This in part explains the rising effect of age after that point on social security wealth. Education and employment status tend to be positive when significant, except in the case of wives' education in the couples equation. Household income is positive but not generally significant, probably because of collinearity with age and education controls used in constructing the social security wealth measures. For this reason these estimates should be seen as descriptive rather than causal.

Next we turn to the fourth panel of Table 6, which describes observed patterns of housing wealth. Age-related patterns are again very strong, particularly for couples: the pattern of housing wealth rises substantially to age 64 , and then levels off. For singles, housing values appear to peak in the 55-64 age range, possibly before retirement. This may reflect the fact that older men and women may give up their homes to move in with their children when they lose a spouse. The relationship with income is generally positive and, surprisingly, in the married couples regression, the squared term is positive and significant. This implies that Japanese households invest more of their income/wealth proportionally in housing wealth, as income increases. These contrasts sharply with equity wealth, where richer people invest less than proportionally as income rises. Once again we find that education is generally positively associated with housing wealth, though weakly. It is surprising that male employment has a 
negative association with levels of housing wealth for both single men and couples; again this may signal that well-to-do retirees are more likely to have a substantial housing asset.

Factors associated with total net wealth in Table 7, where the first three panels focus on the levels of wealth, while the last panel uses the natural log of wealth as the dependent variable. Once again, strong and significant age-related patterns are found for all specifications. In the levels specification, total wealth takes a dip in the 35-44 age range and then climbs after that; the dip is not important in the regressions using the natural log of wealth, however. Total wealth then grows rapidly from the mid 40's onward, with the pattern flattening among the age 65-74 retirement-age group. Again, we confirm that total wealth is greater among households with better educated heads. Marriage, employment status, and male headship appear to have positive but not statistically significant associations with total wealth. Household income is positively and strongly associated with higher wealth in the level and log specifications, and the marginal rate of increase is also increasing in income.

\section{Table 7 here}

In sum, the multivariate results regarding asset holdings and wealth levels in this section may be summarized as follows. First, holding other factors constant, older people are more likely to participate in equity and housing markets, in the Japanese RADAR data. Second, older people hold greater levels of both equity and housing wealth. Third, similar positive links between age and levels of non-equity financial wealth and social security are discerned. Fourth, total wealth is increasing in age. Fifth, holdings of equity, housing wealth, and total wealth all increase with income. However, the mix changes with age: people tend to invest proportionally more in real estate and less in equity as their incomes increase. As to the other factors considered such as 
marriage and sex of household head, only education has a consistently positive impact on equity holdings, housing wealth, and total wealth. Having a working wife has a negative impact on equity holdings, a positive impact on social security wealth, and no statistically significant effect on non-equity financial wealth or housing wealth.

\section{Product Mix and Policy Reform}

Our detailed investigation of lifecycle asset allocation patterns in Japan reinforces many popular priors: that households invest conservatively, other than their family home; that they are risk-averse in their allocation of financial assets; that they have a strong bequest motive generating over-investment in housing and life insurance, the two widely available assets which enjoy preferential bequest tax treatment. These results are important inasmuch as they flow from a much more complete measure of financial and non-financial household wealth than that used in prior analyses.

It should be noted that these choices do not necessarily imply that the Japanese are much more risk-averse than their counterparts in other countries. In the realm of financial assets, the best returns available over the last 20 years in broadly defined Yen-denominated asset classes have been in bank-type deposits. Purchases of foreign-denominated securities, while possible, have been cumbersome in Japan (and elsewhere), and buyers of international assets also confront the additional inhibitor of exchange rate risk. As well, over this period, the riskiness of residential real estate has been revealed to Japanese households more emphatically than to any other developed nation. During the asset boom of the 80s, Japanese household purchases of equities did rise substantially, in spite of cumbersome transactions procedures. Finally, the Government has reduced social security benefits in the face of rapid population aging, and 
households may rationally anticipate further reductions in the future.

It therefore seems possible that the differences between the household asset allocation in Japan and other developed regions of the world may be reasonably explained by an appeal to institutions and policies, and not solely by arguing that Japanese households have extremely riskaverse preferences by international norms. As noted above, a number of tax and regulated institutions were introduced after World War II which offered preference towards bank-type deposits.

It is therefore worth considering whether policy and product reform may go some distance towards generating a household-based asset allocation which might support greater diversification in Japan in the future. This idea appears to underlie the "Big Bang" policy reform, and is one motivation for introducing DC pension plans (Cerulli Associates, 2003). The relatively low proportion of corporate pension wealth in household portfolios revealed by our calculations suggests that there may be inhibitors to investment and returns with these products. The assets tax on certain kinds of pensions, including the new DC pension, is for the moment suspended. But the threat of its re-introduction at some future time will deter many households from making voluntary contributions to these plans. A $1 \%$ assets tax translates into an effective tax rate of perhaps $30 \%$ of benefits over the lifecycle, and is therefore much more severe than the rate, expressed as a percentage of assets, suggests. Related, the current low ceiling on DC contributions inhibits the use of these plans for serious retirement saving.

Low pension investment also raises questions about the adequacy of longevity insurance. What pension wealth there is tends to be taken as a lump sum, although commutation rules are such that annuities are currently becoming somewhat more popular. Annuity and pension 
taxation, however, could be adjusted to favor these types of products.

This aspect of lifecycle asset allocation - the mortality insurance aspect - is given practically no attention in the literature, at least in the broader context of strategic asset allocation. Relative to a typical OECD country, Japanese households purchase more life and less longevity insurance. The greater longevity of the Japanese would suggest that the opposite might have been observed, although later retirement ages in Japan would work in the opposite direction.

Life insurance can of course be held as an offset against over-annuitization through mandatory or public schemes (Bernheim 1991). Our analysis for the moment omits life insurance holdings at the household level, but available evidence indicates this is an unlikely motive for holding life insurance in the Japanese case. Annuitization through social security is not overly generous. The best explanation is that life insurance is a preferential vehicle under the bequest tax legislation. In aggregate, some $17 \%$ of financial assets are held in this form, compared with $10 \%$ in Europe and the USA. Bequest tax reform might be expected therefore to release considerable funds into the financial market in more flexible forms available for investment.

The importance of owner-occupied housing in household portfolios suggests that products could be developed which allowed greater flexibility in the use to which this wealth is put. Our data suggest that many households simultaneously hold substantial bank-type deposits simultaneously with a mortgage, suggesting that bank-type accounts allowing mobility of funds between mortgage and deposit accounts may be a useful innovation. Mortgage contracts may be written with inflexible terms, and we have ascertained that mortgages in Japan are recourse loans, as opposed to the US, where they are effectively non-recourse (except for the very rich). 
Home equity loans existed in the 1980s, but are not now readily available. Recent evidence indicates the feasibility of introducing reverse mortgage contracts into Japan, along with the possibility of using this mechanism to help finance long term care (Mitchell and Piggott, 2004).

A range of policies might be enumerated that would facilitate and support these kinds of product innovations. They include the issue of government bonds which are inflation-indexed, to permit annuity issuers to immunize against future inflation while issuing annuities with constant real value; and the issue of survivor bonds, which would do the same thing for longevity risk faced by annuity issuers. Both these would enable annuity issuers to price their product more attractively.

Secondly, taxation issues are important in understanding asset allocation decisions of households, and there are a number of tax reforms which may encourage more efficient asset allocation. Some of these have been flagged above. Others include the development of taxpreferred individual retirement accounts, and more neutral treatment of risk in the income tax.

\section{Conclusions and Future Research}

This study has evaluated household asset patterns over the lifecycle in Japan, with some comparisons where available for several European nations and the US. Our analysis of life-cycle asset holding patterns used the RADAR data set to evaluate whether factors specific to Japan appear to inhibit efficient allocation of assets during both the accumulation and decumulation phases. We also consider how asset allocation might be improved through the development of a more comprehensive array of contractual saving and investment products. Taking account of home ownership and household claims on social security as well as financial assets and pensions, we investigate both the level and composition of assets. 
Our multivariate analysis is the first to focus on the age patterns of wealth holding and wealth levels in Japan. Most importantly, we find that, holding other factors constant, older people are more likely to participate in equity and housing markets. We also conclude that older people hold greater levels of both equity and housing wealth, and positive links between age and levels of non-equity financial wealth and social security are also found. The evidence also indicates that total wealth is increasing in age. The analysis also showed that holdings of equity, housing wealth, and total wealth all increase with income, but the mix changes with age: people tend to invest proportionally more in real estate and less in equity as their incomes increase. As to the other factors considered such as marriage and sex of household head, only education has a consistently positive impact on equity holdings, housing wealth, and total wealth. Having a working wife has a negative impact on equity holdings, a positive impact on social security wealth, and no statistically significant effect on non-equity financial wealth or housing wealth.

Additional research would be useful to extend the work begun in this paper. For example, we would find it particularly interesting to extend the analysis to additional years of data, which can be done with the RADAR data. This would enable additional analysis of age versus cohort effects alluded to earlier. It would also be of substantial interest to meet with the Nikkei survey section and seek to add additional survey questions regarding respondent labor earnings, the cash value of household insurance policies (or their face values and times to maturity), and pension expectations. A final and very important undertaking would be to add to the wealth figures computed here some amount representing the value of national health entitlements, as well as future long-term care entitlements. Of course these would need to be incorporated net of tax, to produce the proper expected discounted net value of benefit flows. 


\section{References}

Babeau, Andre and Teresa Sbano. "Households Wealth in the National Accounts of Europe, the United States and Japan.” Statistics Directorate Working Paper. OECD: 2003.

Bernheim, B Douglas. "How Strong Are Bequest Motives? Evidence Based on Estimates of the Demand for Life Insurance and Annuities." Journal of Political Economy. 99(5), October 1991: 899-927.

Blomstrom, Magnus, Jennifer Corbett, Fumio Hayashi, and Anil Kashyap. Structural Impediments to Growth in Japan. NBER. Univ. of Chicago Press, 2003.

Cerulli Associates. The Cerulli Report: Japanese Asset Management. Cerulli Associates, Inc. Boston, MA. 2001.

Cerulli Associates. The Cerulli Report: Solutions for Japan. Cerulli Associates, Inc. Boston, MA. 2003.

Clark, Robert and Olivia S. Mitchell. "Strengthening Employment-Based Pensions in Japan." Benefits Quarterly, $2^{\text {nd }}$ Q, 2002: 22-43. Reprinted in The Economics of Social Security in Japan. Ed. Toshiaki Tachibanaki. Surrey, UK: Edward Elgar. 2003.

Iwaisako, Tokuo. "Household Portfolios in Japan". NBER Working Paper No.9647, April 2003.

McCarthy, David. "Household Portfolio Allocation: A Review of the Literature." Presented at the International Collaborative Forum, ESRI, Tokyo, February 2004.

Merton, Robert C. "Lifetime portfolio selection under uncertainty: the continuous-time case." Review of Economics and Statistics 51, 1969: 247-257. 
. "Optimal consumption and portfolio rules in a continuous-time model." Journal of

Economic Theory 3, 1971: 373-413.

Mitchell, Olivia S. "Managing Pensions in the $21^{\text {st }}$ Century: Design Innovations, Market Impact, and Regulatory Issues for Japan.” In Toshihiro Ihori and Toshiaki Tachibanaki, eds. Social Security Reform in Advanced Countries. Routledge: London. 2002: 9-38.

and John Piggott. "Unlocking Housing Equity in Japan". Paper presented at the International Forum for Macroeconomic Issues, Tokyo, February 2003 and at the TRIO conference, December 2003, Tokyo.

, John Piggott, and Satoshi Shimizutani. “Aged-Care Support in Japan: Perspectives and Challenges.” Prepared for presentation at the Tokyo, Japan, February 2004 International Forum organized by the ESRI, Cabinet Office, Government of Japan.

Nakagawa, Shinobu and Tomoko Shimuzu. "Portfolio Selection of Financial Assets by Japan's Households.” Research and Statistics Department, Bank of Japan: 2000.

Nikko Financial Intelligence. Pension Data in Japan. Institute of Pension Research. Tokyo: 2003. http://www.nikko-fi.co.jp/pension/e 03.html

Saino, Jumpei, Satoshi Sugita, Tadanori Chiba, and Tooru Shimada. "New Movements in the Japanese Corporate Pension System.” XXVII International Congress of Actuaries. Cancun, Mexico. March 2002. http://www.actuaries.org/members/en/events/congresses/Cancun/ica2002_subject/pensio $\underline{\text { ns/pensions Xx saino varios.htm }}$

Takayama, Noriyuki. The Morning After in Japan: Its Declining Population, Too Generous 
Pensions and a Weakened Economy. Tokyo: Maruzen Co. Ltd., 1998.

. "Reform of Public and Private Pensions in Japan." Paper presented to Ninth

Annual Colloquium of Superannuation Researchers, The University of New South Wales, Sydney, Australia: 2001.

. Taste of Pie: Searching for Better Pension Provisions in Developed Countries.

Tokyo: Maruzen Co. Ltd., 2003.

Usuki, Masaharu. "Recent Changes to Retirement Benefits in Japan and Relevant Public Policy Issues.” Working Paper, NLI Research Institute, Tokyo, February 2003. 


\section{Appendix: Sources and methods for housing, social security, and pension estimates.}

Since 1983 Nikkei has conducted an annual Consumer Financial Behavior Survey, ${ }^{8}$ a paper and pencil survey administered to 4500 men and women between ages 25 and 74 randomly residing within a $40 \mathrm{~km}$ radius centering on Tokyo Station. Response rates are around 57\%. The survey, 32 pages in length, asks numerous questions about household financial behavior on saving, investment, credit, and loans as well as current topics.

The RADAR data did not adequately account for three important sources of private wealth which we make corrections for in the present study. They are housing, especially housing debt; social security; and occupational pensions. In this appendix, we provide a summary of our approach to valuing each of these net wealth components.

\section{* Housing Equity}

The RADAR data did report an estimate of the market value of housing, the annual loan repayment, and the remaining period of the mortgage. We assume an interest rate of 5\%, and are able to calculate net home equity according to:

Net Home Equity $E=A-\frac{1-(1+i)^{n}}{i} \times p$ where

A: Market of housing

p: Annual repayment amount

$\mathrm{n}$ : Remaining period of repayment of housing loan

i: Rate of interest

Results are incorporated into our estimates of overall wealth.

\section{* Social Security}

The RADAR survey did not provide direct estimates of social security wealth, or individual earnings. However, it did provide other household information, such as age, level of education, employment status and occupation for both household heads and their spouses. We use this information to impute values for these key asset components using the fact that the SS entitlements in Japan are individually-based.

We compute both social security and occupational pension wealth accumulations using the Accumulated Benefit Obligation (ABO) approach rather than a Projected Benefit Obligation (PBO) approach. The ABO value has the advantage that social security and pension entitlements earned to date are thus computed in a manner consistent with the valuation of other assets. All the ABO values were converted into millions of constant yen in 2000 using CPI indexation and $1 \%$ net assumed investment return (AIR\%).

In Japan, social security is vested after 25 years contributions. We have assumed that this occurs at age 45 for everyone. For this reason, there is a sudden jump of SS wealth between age group 
40-44 and 45-49. The ABO of household social security consists of two components - a basic pension, and an earning related component called EPI.

For simplicities, we assume throughout that in multi-person households, the primary workers are males. Survivor benefits accrue only to females.

1. Basic Pension (BP)

We assume that all employees meet the 25 years of contribution requirement. The wives' basic pension wealth is determined by the accumulated years of contribution of their husbands at the point of observation.

Annual BP benefit

$=($ Maximum monthly benefit $x$ Months of coverage $) / 480$ if YOS $>=25$ years ${ }^{9}$

Also actuarial reduction will be applied to those beneficiaries who are younger than age 65 . For example, $72 \%$ of the maximum is paid at age 62 and $58 \%$ at age $60^{10}$

Finally, the $\mathrm{ABO}$ of Basic Pension is calculated by using the appropriate life annuity factor $\ddot{a}_{x}$. In actuarial notation, $\ddot{a}_{x}^{(12)}$ is the present value of annuity of 1 per annum, payable monthly in advance, payable to individual $\mathrm{X}$ [age, gender] until death.

The annuity factors are evaluated using recursive formulae together with monthly payment adjustment.

$$
\begin{aligned}
& \ddot{a}_{x}=1+v \cdot p_{x} \cdot \ddot{a}_{z+1} \\
& \ddot{a}_{\infty}=1
\end{aligned}
$$

where $v=1 /(1+i)$, the discount rate $\mathrm{i}$ is assumed to be $1 \% ; p_{x}$ is the probability for an ..(12) age exact $x$ to survive to age $x+1 .{ }^{11}$ And the monthly payment annuity due factor $a_{x}$ will be estimated approximately. ${ }^{12} \quad \ddot{a}_{x}=\ddot{a}_{x}-\frac{11}{24}$

2. Employment Pension Insurance (EPI)

The RADAR data do not report labour earnings of individuals, so ABOs of EPI were allocated based on an imputed salary. We estimate the household head's salary from ageearnings profiles for individuals in 2000 , differentiated by educational level, published by the Japanese Depart of Labour. ${ }^{13}$

Annual EPI benefit $=$ career average indexed salary $* \mathrm{f} *$ years in coverage. ${ }^{14}$

Where $\mathrm{f}$ is the EPI accrued rate, $0.75 \%$ in 1994 and changed to $0.7125 \%$ in 2000 . 
Again, appropriate life annuity factors were used to calculate ABO of EPIs.

3. Survivor Benefit in EPI

According to Japan social security legislation, it is possible for widows to get extra EPI benefits upon the death of their spouses. In order to avoid double counting, the model only estimates the extra survivors' benefit, which is the maximum of the three pension options available to her under Japanese regulations, less her own EPI pension. ${ }^{15} \mathrm{We}$ ignore any previous transitional regulations for the sake of simplicity.

Thus, the ABO of survivor benefit in EPI

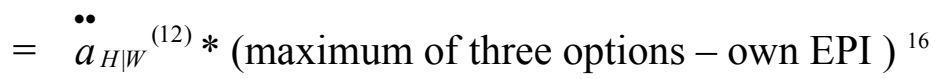

where $\ddot{a}_{H \mid W}{ }^{(12)}$ is the present value of annuity of 1 per year payable monthly to Wife after the death of Husband. It is also called Reversionary Annuity Factor.

\section{- Occupational Pension}

There is almost no information on corporate pensions in the RADAR survey. We therefore made use of estimated present values of pensions reported in Usuki (2003). ${ }^{17}$ These are distinguished by Tenure (years in service) and educational level. We assume that all salary earners belonged to a corporate pension plan, using the salary flag in the RADAR data set to identify these individuals, along with their educational level.

We also assume that each salary earner has an average tenure according to Labor statistics 2000, differentiated by age, gender, level of education and size of firms.

Data used are reproduced below: 


\begin{tabular}{|c|c|c|}
\hline \multirow{2}{*}{ Tenure } & \multicolumn{2}{|c|}{$\mathbf{2 0 0 1}$} \\
\hline Years in Service & $\begin{array}{c}\text { College } \\
\text { Graduates }\end{array}$ & $\begin{array}{c}\text { High School } \\
\text { Graduate }\end{array}$ \\
\hline $\mathbf{0}$ & $\mathbf{0 . 0}$ & $\mathbf{0 . 0}$ \\
\hline 5 & 455.0 & 274.0 \\
\hline 10 & $1,562.0$ & 876.0 \\
\hline 15 & $3,715.0$ & $2,100.0$ \\
\hline 20 & $7,735.0$ & $4,232.0$ \\
\hline 25 & $13,380.0$ & $7,032.0$ \\
\hline 30 & $21,725.0$ & $11,393.0$ \\
\hline 35 & $26,032.8$ & $16,349.0$ \\
\hline 40 & $27,295.0$ & $18,625.0$ \\
\hline
\end{tabular}

\section{References}

Bowers, Newton L., Hans U. Gerber, James C. Hickman, Donald A. Jones, and Cecil J. Nesbitt. 1997. Actuarial Mathematics. 2nd Ed. The Society of Actuaries.

Labor Statistics 2000, Ministry of Health, Labour and Welfare, Japan

http://www.mhlw.go.jp/english/database/db-1/index.html

The $19^{\text {th }}$ Life Table 2000, Ministry of Health,Labour and Welfare, Japan

http://www.mhlw.go.jp/english/database/db-hw/lifetb19th/table-m.html

Noriyuki Takayama 1998. The Morning After In Japan

Usuki, Masaharu. NLI Research Institute. Recent Changes to Retirement Benefits in Japan, and Relevant Public Policy Issues 
Table 1: Household Wealth in 2000: Japan, Europe, and the US (in $2002 €$ )

\begin{tabular}{lccc}
\hline & Japan & Europe & US \\
\hline Financial wealth per household & $€ 180967$ & $€ 119985$ & $€ 270986$ \\
$\begin{array}{l}\text { Financial wealth as percentage of disposable } \\
\text { income }\end{array}$ & $439 \%$ & $338 \%$ & $405 \%$ \\
$\begin{array}{l}\text { Financial liabilities as percentage of } \\
\text { disposable income }\end{array}$ & $99.9 \%$ & $86.5 \%$ & $89.8 \%$ \\
$\begin{array}{l}\text { Residential property wealth } \\
\text { Residential property as percentage of financial }\end{array}$ & 6121181 & $€ 105315$ & $€ 103705$ \\
wealth & & $87.8 \%$ & $38.3 \%$ \\
\hline
\end{tabular}

Source: Babeau and Sbano (2003), Tables 3, 4, 28, and 38. Price conversion at Purchasing Power Parity, end 2002. 
Table 2: Comparison of Composition of Aggregate Household Financial Wealth (end 2000; in \%)

\begin{tabular}{lrrr}
\hline & Japan & Europe & US \\
\hline \hline Currency and deposits & 11.4 & 10.1 & 1.1 \\
Time deposits, saving deposits and others & 41.4 & 17.3 & 9.9 \\
Money market funds & 0.2 & 0.8 & 3.1 \\
Securities other than shares & 4.5 & 6.8 & 6.4 \\
Shares and other equity & 8.3 & 21.3 & 33.1 \\
Mutual funds & 2.4 & 9.5 & 12.9 \\
Life insurance & 17.7 & 17.2 & 7.1 \\
Pension funds & 9.7 & 10.7 & 23.8 \\
Others & 4.4 & 6.2 & 2.5 \\
Total & 100.0 & 100.0 & 100.0 \\
\hline
\end{tabular}

Source: Babeau and Sbano (2003): Table 21. 
Table 3. Summary Statistics for RADAR Analysis Sample (2000)

\begin{tabular}{|c|cccccc|c|}
\hline \multirow{2}{*}{ Variables } & $\begin{array}{c}\text { Social } \\
\text { security } \\
\text { wealth }\end{array}$ & $\begin{array}{c}\text { Housing } \\
\text { equity }\end{array}$ & $\begin{array}{c}\text { Corporate } \\
\text { pension } \\
\text { wealth }\end{array}$ & $\begin{array}{c}\text { Equity } \\
\text { assets }\end{array}$ & $\begin{array}{c}\text { Nonequity } \\
\text { assets }\end{array}$ & $\begin{array}{c}\text { Total } \\
\text { wealth }\end{array}$ & $\begin{array}{c}\text { Monthly } \\
\text { income }\end{array}$ \\
\cline { 2 - 7 } & \multicolumn{7}{c}{ millions of constant yen in 2000} \\
Mean & 23.52 & 24.05 & 6.00 & 1.21 & 8.76 & 66.60 & 706 \\
Median & 20.80 & 8.60 & 3.10 & 0.00 & 3.50 & 51.40 & 650 \\
Std. Err. & 23.12 & 63.08 & 6.85 & 4.54 & 13.74 & 84.59 & 471 \\
Min. & 0.00 & -455.10 & 0.00 & 0.00 & 0.00 & -450.00 & 50 \\
Max. & 72.10 & 977.60 & 33.50 & 50.00 & 100.00 & 1125.40 & 5000 \\
\hline
\end{tabular}

Source: Authors' computations from 2000 RADAR survey; see Appendix. 
Table 4. Probit Models of Equity and Housing Wealth Holding $(0,1)$ Dep.Var: Equity holding

\begin{tabular}{|c|c|c|c|c|c|c|c|c|c|c|c|}
\hline \multicolumn{4}{|c|}{ Group: single male } & \multicolumn{4}{|c|}{ Group: single female } & \multicolumn{4}{|c|}{ Group: couples } \\
\hline & Coeff. & Std.Err & z-stat & & Coeff. & Std.Err & z-stat & & Coeff. & Std.Err & z-stat \\
\hline \multirow{5}{*}{$\begin{array}{l}\text { education_m } \\
\text { employ_m } \\
\text { income } \\
\text { salary_based } \\
35-44\end{array}$} & 0.259 & 0.125 & 2.06 & education_f & 0.287 & 0.178 & 1.61 & education_m & 0.203 & 0.037 & 5.45 \\
\hline & -0.297 & 0.435 & -0.68 & employ_f & -0.031 & 0.412 & -0.08 & employ_m & -0.629 & 0.129 & -4.86 \\
\hline & 0.031 & 0.046 & 0.68 & income & 0.161 & 0.060 & 2.69 & education_f & 0.046 & 0.046 & 1 \\
\hline & -0.879 & 0.311 & -2.82 & salary_base & -0.991 & 0.418 & -2.37 & employ_f & -0.206 & 0.069 & -2.99 \\
\hline & 0.498 & 0.318 & 1.57 & $35-44$ & -0.153 & 0.459 & -0.33 & income & 0.159 & 0.018 & 8.87 \\
\hline $45-54$ & 0.257 & 0.419 & 0.61 & $45-54$ & 0.139 & 0.441 & 0.31 & income ${ }^{\wedge} 2$ & -0.003 & 0.000 & -5.94 \\
\hline $55-64$ & 1.064 & 0.436 & 2.44 & $55-64$ & 0.248 & 0.494 & 0.5 & salary_basec & 0.157 & 0.107 & 1.47 \\
\hline $65-74$ & -0.082 & 0.610 & -0.13 & $65-74$ & 0.358 & 0.576 & 0.62 & $35-44$ & 0.172 & 0.131 & 1.31 \\
\hline \multirow[t]{4}{*}{ cons } & -1.437 & 0.597 & -2.41 & cons & -2.159 & 0.711 & -3.04 & $45-54$ & 0.482 & 0.129 & 3.72 \\
\hline & & & & & & & & $55-64$ & 0.920 & 0.134 & 6.89 \\
\hline & & & & & & & & $65-75$ & 0.797 & 0.161 & 4.96 \\
\hline & & & & & & & & cons & -2.403 & 0.200 & -12 \\
\hline \multirow{2}{*}{\multicolumn{4}{|c|}{$\begin{array}{l}\text { Nobs=221 } \\
\text { Log likelihood }=-67.07\end{array}$}} & \multicolumn{4}{|l|}{ Nobs $=224$} & \multicolumn{4}{|l|}{ Nobs $=2021$} \\
\hline \multirow{2}{*}{\multicolumn{4}{|c|}{$\begin{array}{l}\text { Log likelihood }=-67.07 \\
\text { Pseudo R2 }=0.183\end{array}$}} & \multirow{2}{*}{\multicolumn{4}{|c|}{ Log likelihood $=-57.22$}} & \multicolumn{4}{|c|}{ Log likelihood $=-971.10$} \\
\hline & & & & & & & & Pseudo R2 & 0.162 & & \\
\hline
\end{tabular}

Dep.Var: Own Housing

\begin{tabular}{|c|c|c|c|c|c|c|c|c|c|c|c|}
\hline \multicolumn{4}{|c|}{ Group: single male } & \multicolumn{4}{|c|}{ Group: single female } & \multicolumn{4}{|c|}{ Group: couples } \\
\hline & Coeff. & Std.Err & z-stat & & Coeff. & Std.Err & z-stat & & Coeff. & Std.Err & z-stat \\
\hline education_m & 0.153 & 0.086 & 1.77 & education_f & -0.013 & 0.129 & -0.1 & education_m & 0.025 & 0.038 & 0.66 \\
\hline employ_m & -0.803 & 0.374 & -2.15 & employ_f & -0.180 & 0.306 & -0.59 & employ_m & -0.967 & 0.181 & -5.34 \\
\hline income & 0.094 & 0.042 & 2.23 & income & 0.094 & 0.052 & 1.82 & education_f & -0.014 & 0.049 & -0.28 \\
\hline salary_based & 0.053 & 0.273 & 0.19 & salary_baseı & 0.161 & 0.319 & 0.51 & employ_f & 0.068 & 0.071 & 0.96 \\
\hline $35-44$ & 0.321 & 0.264 & 1.22 & $35-44$ & -0.152 & 0.277 & -0.55 & income & 0.133 & 0.019 & 6.89 \\
\hline $45-54$ & -0.227 & 0.329 & -0.69 & $45-54$ & -0.490 & 0.311 & -1.58 & income ${ }^{\wedge} 2$ & -0.003 & 0.001 & -4.68 \\
\hline $55-64$ & 0.201 & 0.383 & 0.53 & $55-64$ & 0.169 & 0.407 & 0.41 & salary_basec & 0.066 & 0.107 & 0.61 \\
\hline $65-74$ & -0.058 & 0.464 & -0.13 & $65-74$ & 0.472 & 0.468 & 1.01 & $35-44$ & 0.372 & 0.099 & 3.75 \\
\hline cons & 0.143 & 0.469 & 0.3 & cons & 0.438 & 0.513 & 0.85 & $45-54$ & 0.898 & 0.106 & 8.46 \\
\hline & & & & & & & & $55-64$ & 1.343 & 0.124 & 10.82 \\
\hline & & & & & & & & $65-75$ & 1.407 & 0.172 & 8.18 \\
\hline & & & & & & & & cons & 0.001 & 0.213 & 0.01 \\
\hline Nobs $=221$ & & & & Nobs $=220$ & & & & Nobs $=2014$ & & & \\
\hline Log lit & 6.15 & & & Log likelihood & -119.65 & & & Log likelihood & 395.14 & & \\
\hline Pseudo R2 & 0.059 & & & Pseudo R2 & 0.041 & & & Pseudo R2 & 0.183 & & \\
\hline
\end{tabular}

Source: Authors' computations from 2000 RADAR survey; see Appendix. 
Table 6. Tobit Models of Wealth Levels by Asset and Household Type

\begin{tabular}{|c|c|c|c|c|c|c|c|c|c|c|c|}
\hline \multicolumn{4}{|c|}{ Group: single males } & \multicolumn{4}{|c|}{ Group: single females } & \multicolumn{4}{|c|}{ Group: couples } \\
\hline & Coeff. & Std.Err & $z$-stat & & Coeff. & Std.Err & z-stat & \multicolumn{2}{|r|}{ Coeff. } & \multirow{2}{*}{$\frac{\text { Std.Err }}{0.36}$} & \multirow{2}{*}{$\frac{z \text {-stat }}{6.17}$} \\
\hline \multirow{5}{*}{$\begin{array}{l}\text { education_m } \\
\text { employ_m } \\
\text { income } \\
\text { salary_basec } \\
35-44\end{array}$} & 0.98 & 0.71 & 1.37 & education $f$ & 4.12 & 2.01 & 2.05 & education $n$ & 2.24 & & \\
\hline & -1.02 & 2.46 & -0.42 & employ_f & 0.91 & 4.57 & 0.20 & employ_m & -7.38 & 1.20 & -6.14 \\
\hline & 0.23 & 0.26 & 0.88 & income & 1.61 & 0.72 & 2.23 & education_f & -0.03 & 0.44 & -0.07 \\
\hline & -6.38 & 1.82 & -3.50 & salary_basec & -9.33 & 4.80 & -1.94 & employ_f & -2.10 & 0.66 & -3.17 \\
\hline & 3.18 & 1.84 & 1.73 & $35-44$ & -0.61 & 5.12 & -0.12 & income & 1.53 & 0.17 & 9.15 \\
\hline $45-54$ & 1.08 & 2.46 & 0.44 & $45-54$ & 5.59 & 4.67 & 1.20 & income ${ }^{\wedge} 2$ & -0.03 & 0.00 & -5.63 \\
\hline $55-64$ & 7.98 & 2.40 & 3.33 & $55-64$ & 4.97 & 5.45 & 0.91 & salary_base & 0.68 & 1.03 & 0.66 \\
\hline $65-74$ & -1.68 & 3.50 & -0.48 & $65-74$ & 8.20 & 6.37 & 1.29 & $35-44$ & 1.44 & 1.33 & 1.09 \\
\hline cons & -6.86 & 3.58 & -1.91 & cons & -30.23 & 9.05 & -3.34 & $45-54$ & 4.10 & 1.30 & 3.15 \\
\hline \multirow[t]{4}{*}{ se } & 5.88 & 0.90 & NA & se & 11.07 & 1.95 & NA & $55-64$ & 7.89 & 1.34 & 5.90 \\
\hline & & & & & & & & $65-75$ & 8.66 & 1.56 & 5.56 \\
\hline & & & & & & & & cons & -22.34 & 2.04 & -10.94 \\
\hline & & & & & & & & se & 10.18 & 0.34 & NA \\
\hline \multirow{2}{*}{\multicolumn{4}{|c|}{$\begin{array}{l}\text { Nobs }=221(194 \text { censored }) \\
\text { Log likelihood }=-125.77\end{array}$}} & \multirow{2}{*}{\multicolumn{4}{|c|}{$\begin{array}{l}\text { Nobs }=224(204 \text { censored }) \\
\text { Log likelihood }=-109.84\end{array}$}} & \multicolumn{4}{|c|}{ Nobs $=2021$ (1495 censored) } \\
\hline & & & & \multirow{2}{*}{\multicolumn{4}{|c|}{ Log likelihood $=-109.84$}} & \multicolumn{4}{|c|}{ Log likelihood $=-2466.14$} \\
\hline Pseudo R2 & \multicolumn{3}{|c|}{ Log likelihood $=-125.77$} & & & & & Pseudo R2 & $=0.0$ & & \\
\hline
\end{tabular}

\begin{tabular}{|c|c|c|c|c|c|c|c|c|c|c|c|}
\hline \multicolumn{4}{|c|}{ Group: single males } & \multicolumn{4}{|c|}{ Group: single females } & \multicolumn{4}{|c|}{ Group: couples } \\
\hline & Coeff. & Std.Err & $z$-stat & & Coeff. & Std.Err & z-stat & & Coeff. & Std.Err & $z$-stat \\
\hline \multirow{8}{*}{$\begin{array}{l}\text { education_m } \\
\text { employ_m } \\
\text { income } \\
\text { salary_basec } \\
\text { under 44 } \\
45-54 \\
55-64 \\
\text { cons }\end{array}$} & 0.52 & 0.59 & 0.88 & education_f & 1.70 & 0.73 & 2.31 & education_n & 0.74 & 0.30 & 2.44 \\
\hline & -6.64 & 2.38 & -2.79 & employ_f & -2.36 & 1.76 & -1.34 & employ_m & -6.02 & 1.14 & -5.26 \\
\hline & 0.95 & 0.25 & 3.82 & income & 1.16 & 0.27 & 4.30 & education_f & 0.97 & 0.40 & 2.46 \\
\hline & 2.70 & 1.89 & 1.43 & salary_basec & -4.14 & 1.85 & -2.24 & employ_f & -0.32 & 0.58 & -0.55 \\
\hline & -13.67 & 2.96 & -4.61 & under 44 & -3.41 & 2.41 & -1.41 & income & 0.96 & 0.06 & 14.96 \\
\hline & -10.23 & 3.34 & -3.06 & $45-54$ & -1.11 & 2.44 & -0.45 & income ${ }^{\wedge} 2$ & -1.31 & 0.86 & -1.51 \\
\hline & -10.77 & 3.55 & -3.03 & $55-64$ & 7.96 & 2.45 & 3.25 & salary_base & -24.99 & 2.95 & -8.47 \\
\hline & 15.04 & 3.03 & 4.96 & cons & 3.42 & 1.95 & 1.76 & $35-44$ & -24.12 & 2.95 & -8.18 \\
\hline \multirow[t]{4}{*}{ _se } & 8.99 & 0.43 & NA & se & 8.20 & 0.39 & NA & $45-54$ & -16.12 & 2.91 & -5.53 \\
\hline & & & & & & & & $55-64$ & -12.35 & 2.88 & -4.29 \\
\hline & & & & & & & & $65-75$ & 24.98 & 2.86 & 8.73 \\
\hline & & & & & & & & se & 12.34 & 0.20 & NA \\
\hline \multirow{2}{*}{\multicolumn{4}{|c|}{$\begin{array}{l}\text { Nobs }=221(4 \text { censored }) \\
\text { Log likelihood }=-787.49\end{array}$}} & \multirow{2}{*}{\multicolumn{4}{|c|}{$\begin{array}{l}\text { Nob }=220(0 \text { censored }) \\
\text { Log likelihood }=-789.21\end{array}$}} & \multicolumn{4}{|c|}{ Nobs $=2021$ (31 uncensored) } \\
\hline & & & & & & & & Log likelihood = & -7856.10 & & \\
\hline \multicolumn{4}{|c|}{ Pseudo R2 $=0.037$} & Pseudo R2 = & 0.045 & & & Pseudo R2 & 0.039 & & \\
\hline
\end{tabular}

\begin{tabular}{|c|c|c|c|c|c|c|c|c|c|c|c|}
\hline \multicolumn{4}{|c|}{ Group: single males } & \multicolumn{4}{|c|}{ Group: single females } & \multicolumn{4}{|c|}{ Group: couples } \\
\hline & Coeff. & Std.Err & z-stat & & Coeff. & Std.Err & $z$-stat & & Coeff. & Std.Err & $z$-stat \\
\hline \multirow{5}{*}{$\begin{array}{l}\text { education_m } \\
\text { employ_m } \\
\text { income } \\
\text { salary_basec } \\
\text { under44 }\end{array}$} & 1.660 & 0.506 & 3.28 & education_f & 0.268 & 0.481 & 0.56 & education_n & 2.558 & 0.274 & 9.35 \\
\hline & 4.989 & 1.464 & 3.41 & employ_f & 14.501 & 0.905 & 16 & employ_m & 5.759 & 0.875 & 6.59 \\
\hline & 0.185 & 0.184 & 1 & income & 0.327 & 0.135 & 2.4 & education_f & -0.809 & 0.364 & -2.22 \\
\hline & -2.313 & 1.214 & -1.9 & salary_basec & -2.338 & 0.962 & -2.4 & employ_f & 7.317 & 0.535 & 13.67 \\
\hline & -54.245 & NA & NA & under44 & -41.592 & NA & NA & income & 0.222 & 0.052 & 4.32 \\
\hline $45-54$ & -4.910 & 1.501 & -3.3 & $45-54$ & -0.327 & 0.982 & -0.3 & salary_base & -0.934 & 0.711 & -1.31 \\
\hline $55-64$ & 6.309 & 1.586 & 3.98 & $55-64$ & 5.104 & 0.937 & 5.45 & under34 & -108.899 & NA & NA \\
\hline cons & 17.457 & 1.780 & 9.81 & cons & 6.440 & 0.917 & 7.02 & $35-44$ & -63.506 & 2.418 & -26.27 \\
\hline \multirow[t]{5}{*}{ se } & 3.770 & 0.381 & NA & _se & 2.966 & 0.227 & NA & $45-54$ & -10.611 & 2.187 & -4.85 \\
\hline & & & & & & & & $55-64$ & 7.864 & 2.157 & 3.65 \\
\hline & & & & & & & & $65-74$ & 6.398 & 2.125 & 3.01 \\
\hline & & & & & & & & cons & 29.954 & 2.144 & 13.97 \\
\hline & & & & & & & & se & 9.111 & 0.182 & NA \\
\hline \multirow{2}{*}{\multicolumn{4}{|c|}{$\begin{array}{l}\text { Nobs=221 }(172 \text { censored }) \\
\text { Log likelihood }=-134.55\end{array}$}} & \multirow{2}{*}{\multicolumn{4}{|c|}{ Nobs=220 (139censored) }} & \multicolumn{4}{|c|}{$\overline{\text { Nobs }=2021 \text { (752 censored })}$} \\
\hline & & & & & & & & Log likelihood = & $=-4656.71$ & & \\
\hline \multicolumn{4}{|l|}{ Pseudo R2 } & Pseudo R2 & 0.535 & & & Pseudo R2 & $=0.334$ & & \\
\hline
\end{tabular}

Dep.Var.: Housing wealth

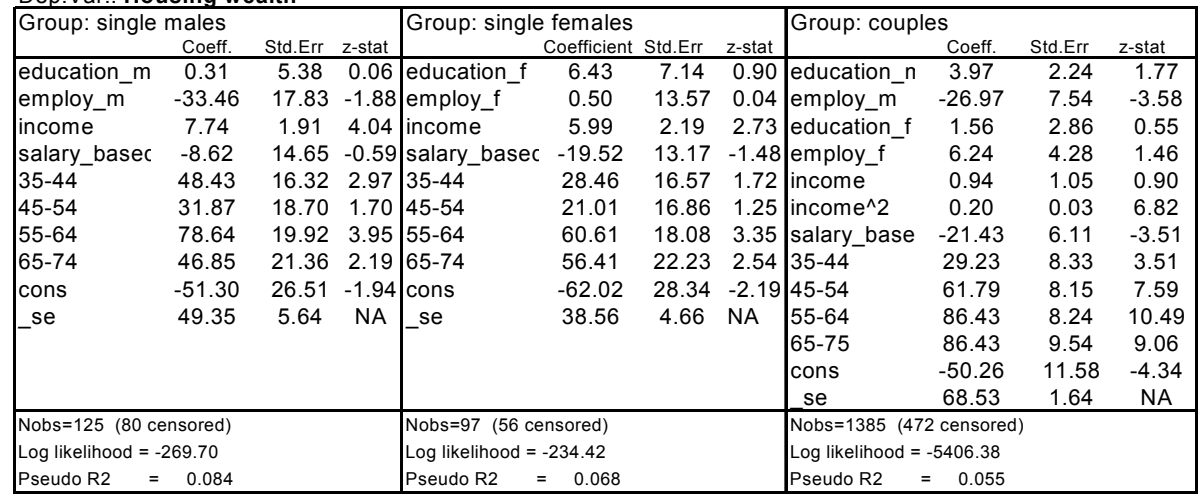

Source: Authors' computations from 2000 RADAR survey; see Appendix. 
Table 7. OLS Models of Total Wealth: Pooled Sample

Dep.Var.: Total Wealth

Dep.Var.: Total Wealth

\begin{tabular}{|c|c|c|c|c|c|c|c|}
\hline & \multicolumn{2}{|c|}{ Coefficient Std.Err } & Z-stat & & Coefficient & \multirow{2}{*}{ Std.Err } & \multirow{2}{*}{$\begin{array}{l}\text { z-stat } \\
0.170\end{array}$} \\
\hline married & 6.655 & 10.990 & 0.610 & married & 1.058 & & \\
\hline education & 9.214 & 4.444 & 2.070 & education & 5.234 & 2.282 & 2.290 \\
\hline employ & 4.842 & 4.667 & 1.040 & employment & 1.199 & 2.499 & 0.480 \\
\hline $\operatorname{sex}$ & 12.913 & 9.259 & 1.390 & $\operatorname{sex}$ & 3.947 & 5.287 & 0.750 \\
\hline salary_basec & ( -12.493 & 4.635 & -2.700 & income & 6.084 & 1.345 & 4.520 \\
\hline $35-44$ & -3.255 & 5.283 & -0.620 & salary based & -26.455 & 6.416 & -4.120 \\
\hline $45-54$ & 62.766 & 5.212 & 12.040 & $35-44$ & -13.693 & 3.958 & -3.460 \\
\hline $55-64$ & 109.276 & 5.553 & 19.680 & $45-54$ & 41.364 & 4.779 & 8.660 \\
\hline $65-74$ & 100.993 & 6.738 & 14.990 & $55-64$ & 89.899 & 5.336 & 16.850 \\
\hline \multirow[t]{3}{*}{ cons } & -31.027 & 11.807 & -2.630 & $65-74$ & 57.335 & 18.607 & 3.080 \\
\hline & & & & incomex65-74 & 6.086 & 3.739 & 1.630 \\
\hline & & & & cons & -17.357 & 7.824 & -2.220 \\
\hline Nobs $=17$ & & & & Nobs $=1746$ & & & \\
\hline $2=0$ & Adj. $R 2=0.342$ & & & $\mathrm{R} 2=0.474$ & raj. & & \\
\hline
\end{tabular}

Dep.Var.: Total Wealth

Dep.Var.:Ln(Total Wealth)

\begin{tabular}{|lccc|lccc|}
\hline & Coefficient & Std.Err & z-stat & & Coefficient & Std.Err & z-stat \\
\hline married & 7.208 & 5.980 & 1.210 & married & 0.265 & 0.179 & 1.480 \\
education & 7.062 & 2.178 & 3.240 & education & 0.127 & 0.070 & 1.810 \\
employment & 1.430 & 2.475 & 0.580 & employment & 0.142 & 0.155 & 0.920 \\
sex & 8.091 & 5.049 & 1.600 & sex & -0.005 & 0.071 & -0.060 \\
income & -0.426 & 2.109 & -0.200 & log_income & 0.493 & 0.051 & 9.620 \\
income^2 & 0.207 & 0.094 & 2.200 & salary_based & -0.204 & 0.080 & -2.560 \\
salary_basec & -18.990 & 5.782 & -3.280 & $35-44$ & 0.798 & 0.098 & 8.110 \\
$35-44$ & -7.059 & 3.319 & -2.130 & $45-54$ & 2.534 & 0.089 & 28.470 \\
$45-54$ & 49.631 & 4.433 & 11.190 & $55-64$ & 3.123 & 0.091 & 34.140 \\
$55-64$ & 96.119 & 3.866 & 24.860 & $65-74$ & 3.139 & 0.111 & 28.180 \\
65-74 & 57.840 & 22.316 & 2.590 & cons & 0.088 & 0.195 & 0.450 \\
incomex65-7 & 6.590 & 4.451 & 1.480 & & & & \\
cons & -11.870 & 8.229 & -1.440 & & & & \\
\hline Nobs=1746 & & & & Nobs=1696 & & & \\
R2=0.499 & Adj.R2=0.495 & & & & & & \\
\hline
\end{tabular}

Source: Authors' computations from 2000 RADAR survey; see Appendix. 


\section{Chart 1: Life Cycle Asset Levels and Allocation in Japan 2000} (Median Value)

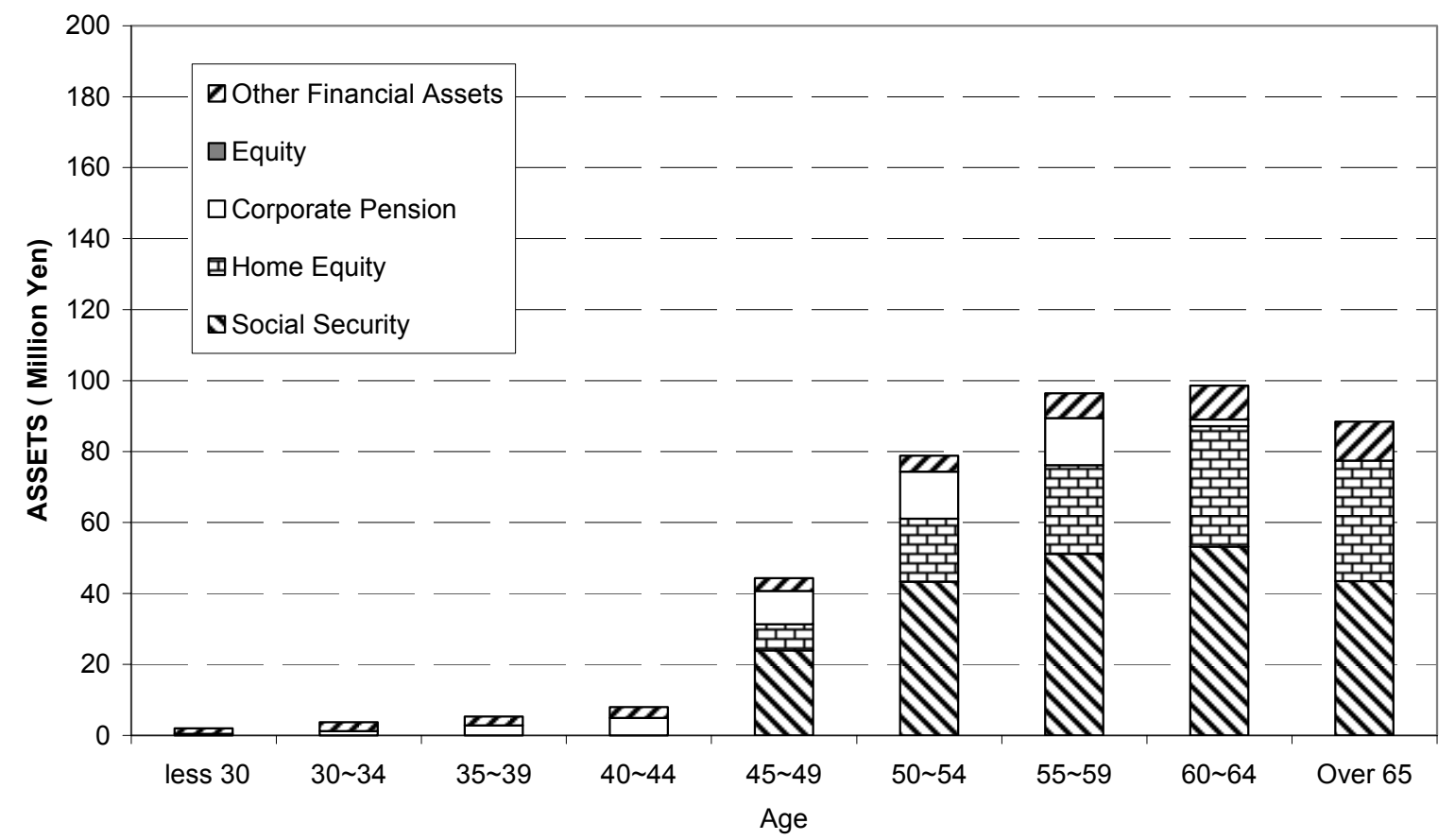

Source: Authors' computations from 2000 RADAR survey; see Appendix. 
Chart 2a: Life Cycle Asset Levels and Allocation in Japan 2000 (Median)

HH Type: Couple_FW_Wife

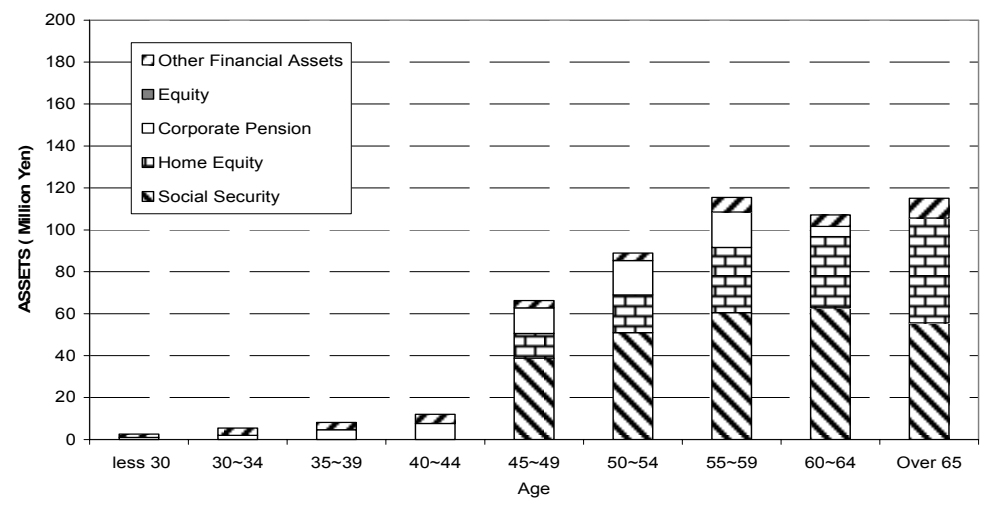

Chart 2b: Life Cycle Asset Levels and Allocation in Japan 2000 (Median) HH Type: Couple_PW_Wife

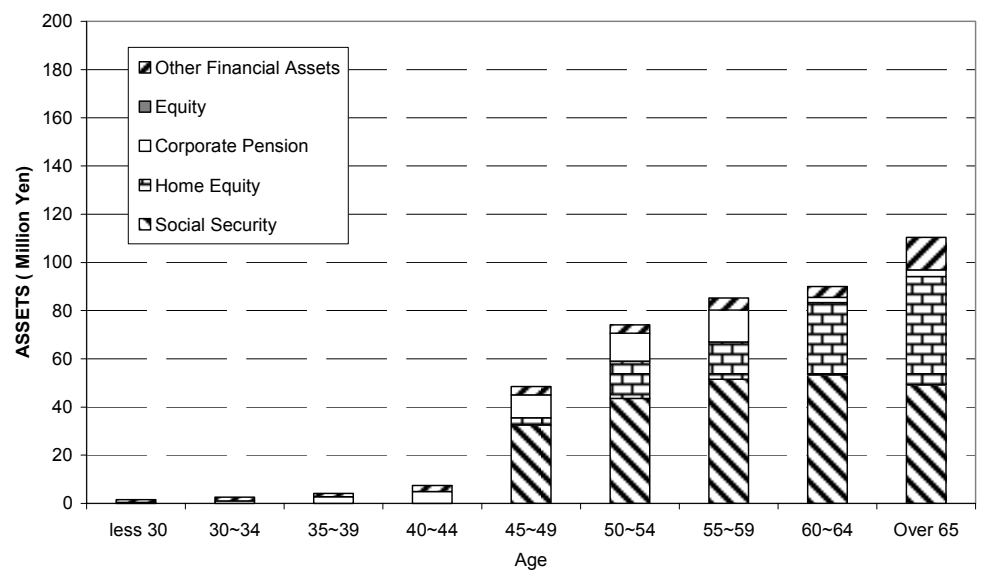

Chart 2c: Life Cycle Asset Levels and Allocation in Japan 2000 (Median) HH Type: Couple_HouseWife

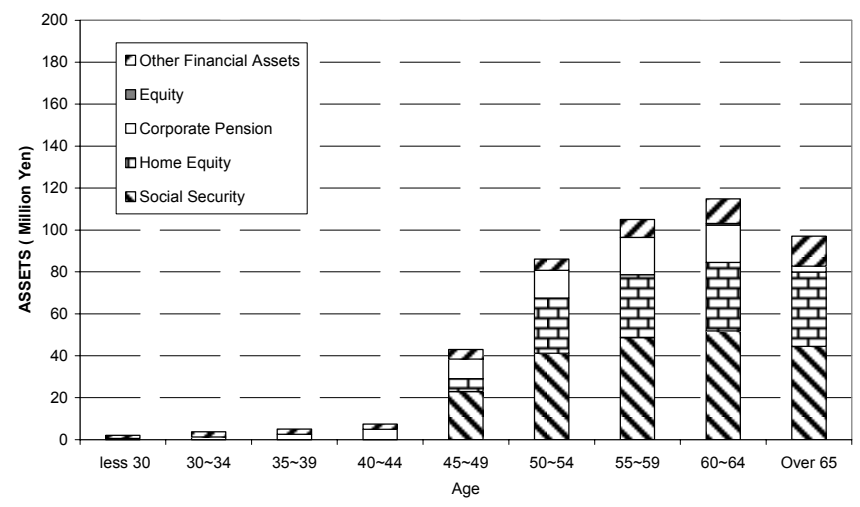

Source: Authors' computations from 2000 RADAR survey; see Appendix. 
Chart 3a: Life Cycle Asset Levels and Allocation in Japan 2000 (Median) HH Type: SingleMale

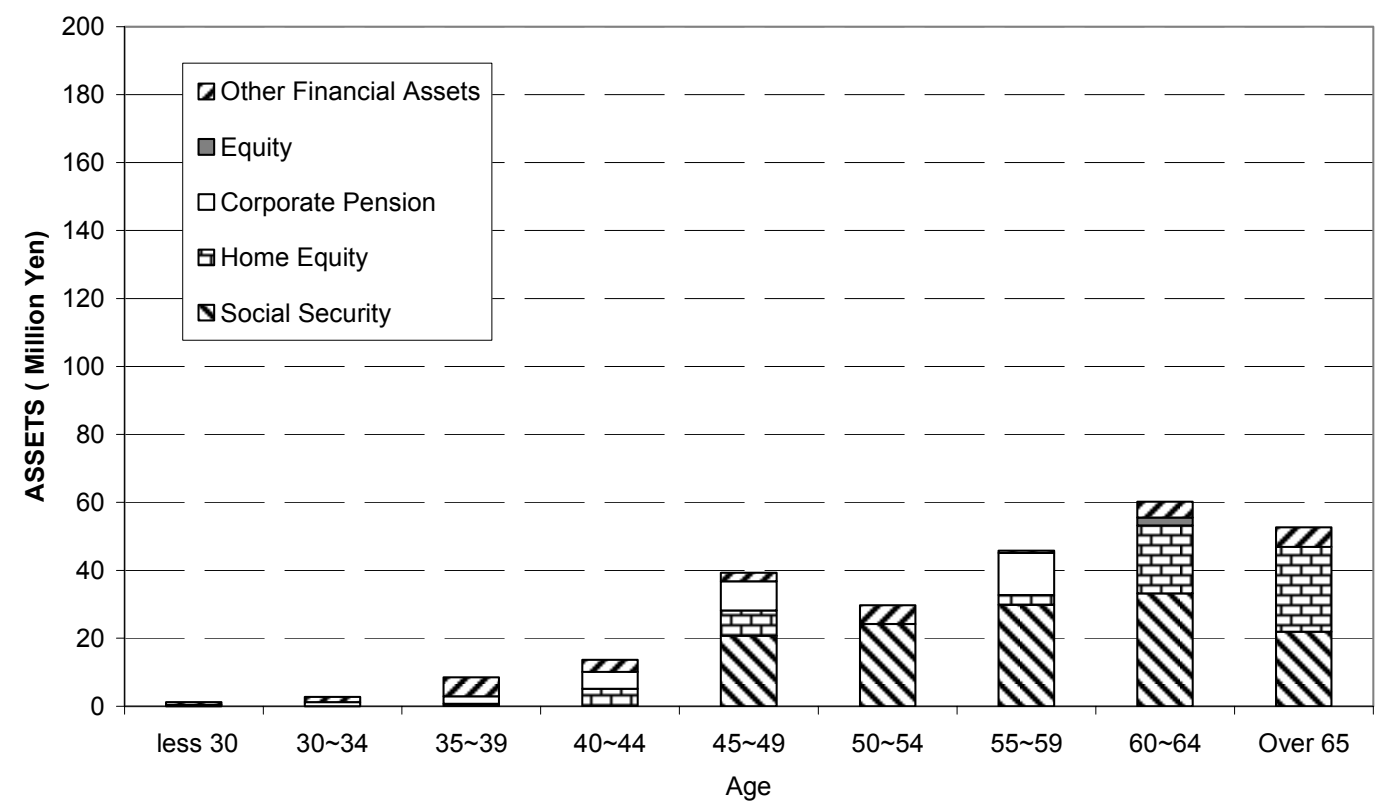

Chart 3b: Life Cycle Asset Levels and Allocation in Japan 2000 (Median) HH Type: SingleFemale

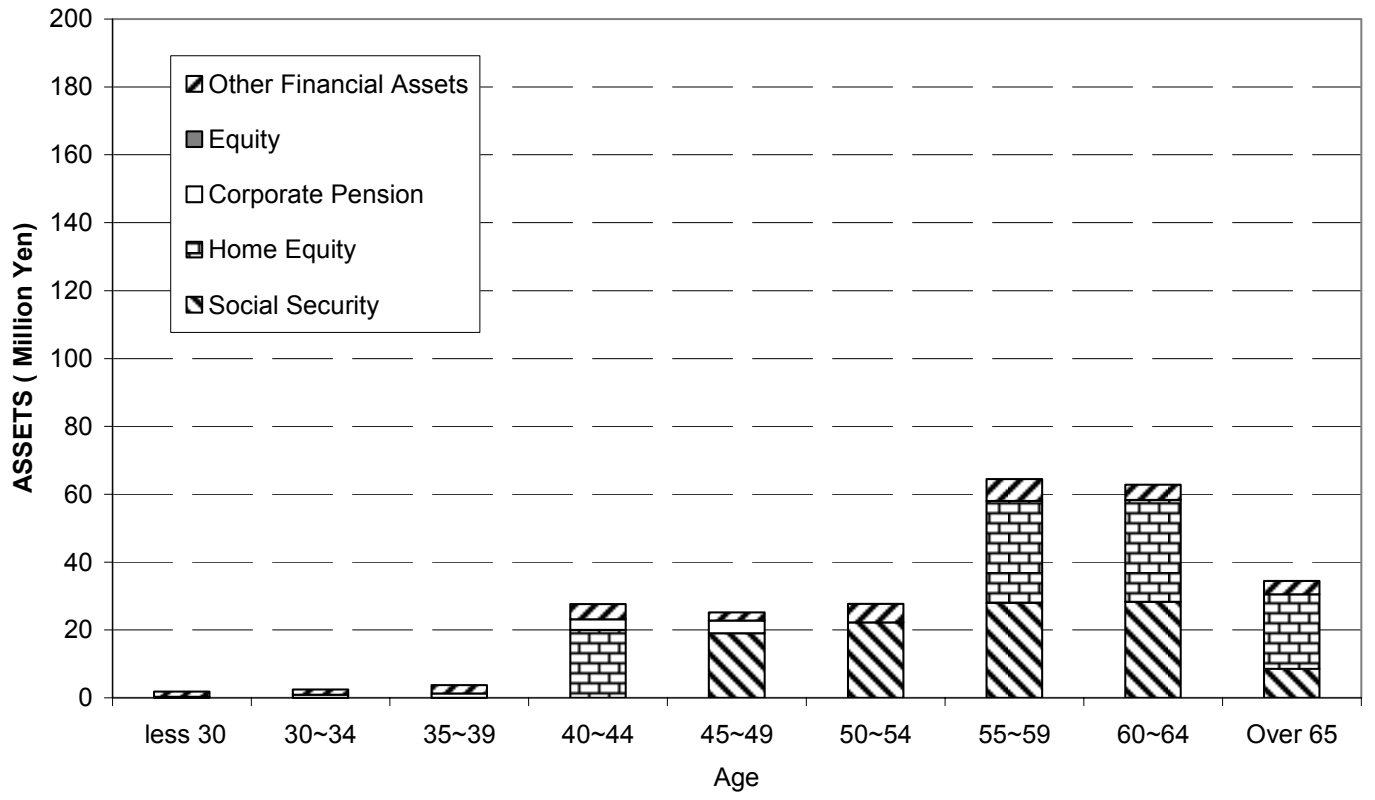

Source: Authors' computations from 2000 RADAR survey; see Appendix. 


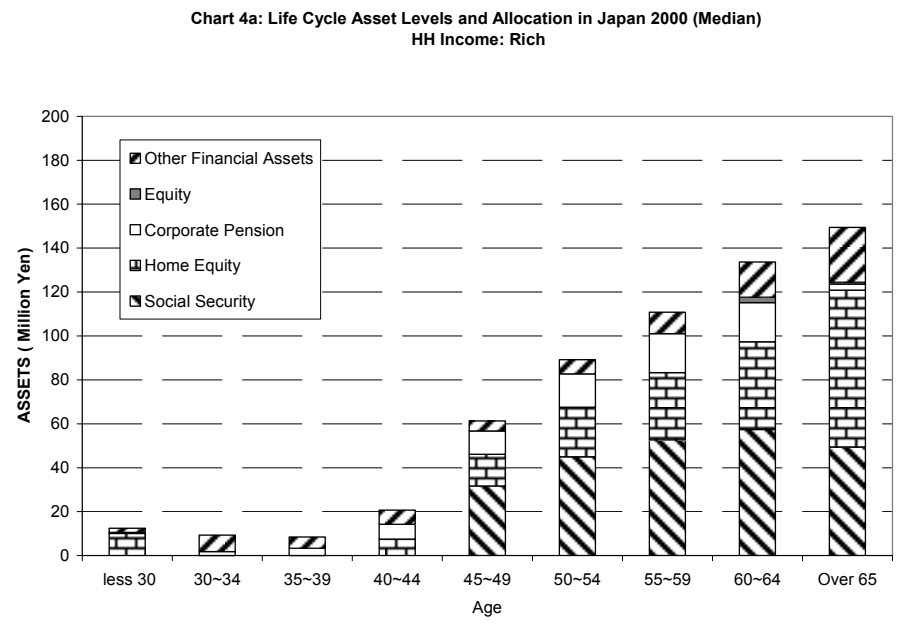

Chart 4b: Life Cycle Asset Levels and Allocation in Japan 2000 (Median) HH Income: Middle

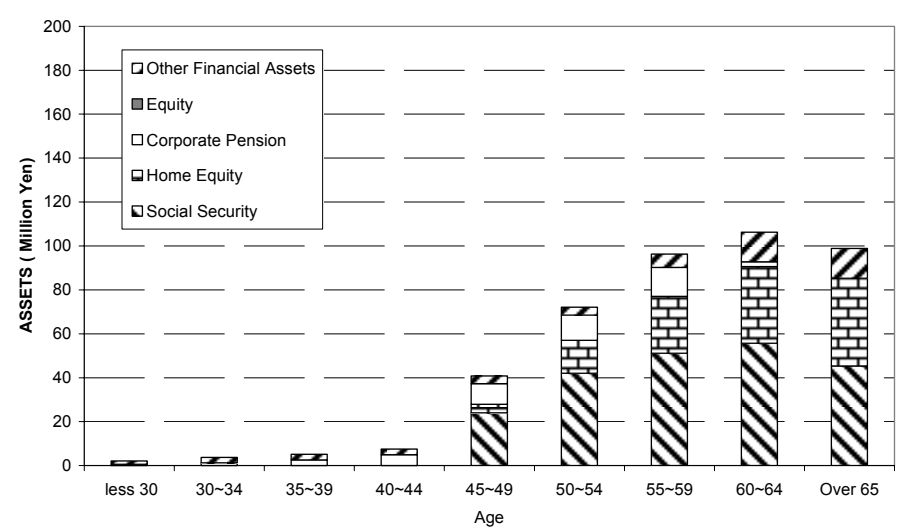

Chart 4c: Life Cycle Asset Levels and Allocation in Japan 2000 (Median) HH Income: Poor

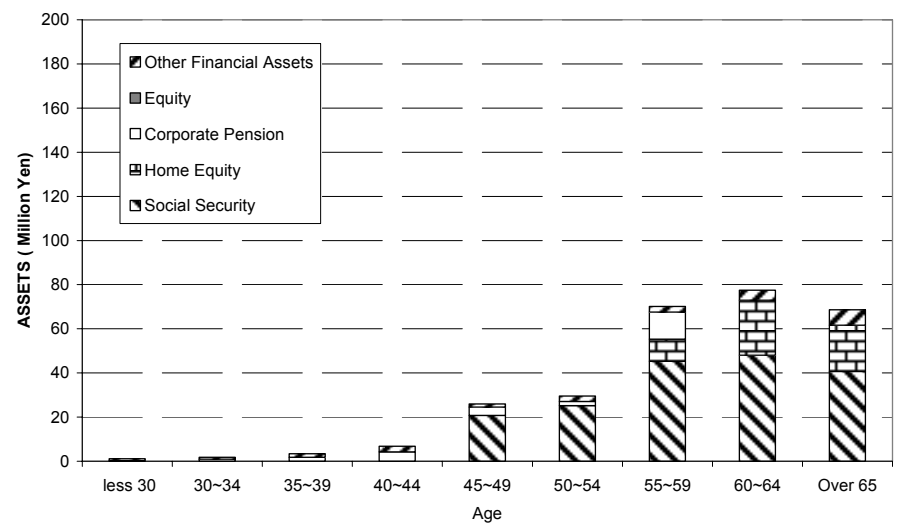

Source: Authors' computations from 2000 RADAR survey; see Appendix. 


\section{Endnotes}

${ }^{1}$ Recent references on the pension system include Clark and Mitchell (2002); Cerulli Associates (2001, 2003); Nikko Financial Intelligence (2003), Shimada et al. (2002); and Usuki (2003).

${ }^{2}$ See for instance the articles in Blomstrom et al. (2003).

${ }^{3}$ This reduces the usable sample size to about 1,800 for our regression analysis.

${ }^{4}$ Additional data were generously provided by Masaharu Usuki via personal communication. ${ }^{5}$ The questionnaire asks only about face value of the life insurance policy without any maturity date; additional clarification will be sought in future surveys. As Table 2 suggests, this may be a major omission for Japan, where life insurance is in aggregate has been valued at $17 \%$ of total financial wealth. In future research, we hope to develop an adequate approach to its valuation. ${ }^{6}$ While we provide a lifecycle interpretation of our findings, we are award that with crosssection data, age and cohort effects are conflated. We hope to explore this point further in future research.

${ }^{7}$ We also caution the reader that some cells have only a small number of observations.

${ }^{8}$ See http://www.nqi.co.jp/english/needs/n_top.html

${ }^{9}$ The maximum BP monthly benefit was taken from page 22 Takayama (1998). The maximum benefit in 2000 is JPY 67017.

${ }^{10}$ See also Table 2.2 on page 23, Takayama (1998) for detailed actuarial reduction rate.

${ }^{11}$ See also Japan Life Table 2000

${ }^{12}$ See Bowers (1997, p 151) for more details.

${ }^{13}$ Please refer to http://www.mhlw.go.jp/english/database/db-1/index.html for details

${ }^{14}$ The EPI accrual rate $0.75 \%$ was replaced by a time series (Takayama 1998, p 23)

${ }^{15}$ Three options for survivors. (1) Her own EPI only (2) 3/4 of husband's EPI (3) 2/3 of husband's EPI plus $1 / 2$ of her own EPI. 
${ }^{16}$ See Bowers (1997), p 285 for more details

${ }^{17}$ Additional data were generously provided by Masaharu Usuki via personal communication. 